\title{
Sodium thiosulfate attenuates glial- mediated neuroinflammation in degenerative neurological diseases
}

\author{
Moonhee Lee, Edith G. McGeer and Patrick L. McGeer
}

\begin{abstract}
Background: Sodium thiosulfate (STS) is an industrial chemical which has also been approved for the treatment of certain rare medical conditions. These include cyanide poisoning and calciphylaxis in hemodialysis patients with end-stage kidney disease. Here, we investigated the anti-inflammatory activity of STS in our glial-mediated neuroinflammatory model.
\end{abstract}

Methods: Firstly, we measured glutathione (GSH) and hydrogen sulfide $\left(\mathrm{H}_{2} \mathrm{~S}, \mathrm{SH}^{-}\right)$levels in glial cells after treatment with sodium hydrosulfide (NaSH) or STS. We also measured released levels of tumor necrosis factor-a (TNFa) and interleukin-6 (IL-6) from them. We used two cell viability assays, MTT and lactate dehydrogenase (LDH) release assays, to investigate glial-mediated neurotoxicity and anti-inflammatory effects of NaSH or STS. We also employed Western blot to examine activation of intracellular inflammatory pathways.

Results: We found that STS increases $\mathrm{H}_{2} \mathrm{~S}$ and GSH expression in human microglia and astrocytes. When human microglia and astrocytes are activated by lipopolysaccharide (LPS)/interferon- $\gamma$ (IFNY) or IFNY, they release materials that are toxic to differentiated SH-SY5Y cells. When the glial cells were treated with NaSH or STS, there was a significant enhancement of neuroprotection. The effect was concentration-dependent and incubation time-dependent. Such treatment reduced the release of TNFa and IL-6 and also attenuated activation of P38 MAPK and NFKB proteins. The compounds tested were not harmful when applied directly to all the cell types.

Conclusions: Although NaSH was somewhat more powerful than STS in these in vitro assays, STS has already been approved as an orally available treatment. STS may therefore be a candidate for treating neurodegenerative disorders that have a prominent neuroinflammatory component.

Keywords: NaSH, Neurotoxicity, TNFa, IL-6, Alzheimer's disease, Parkinson's disease

\section{Background}

Sodium thiosulphate $\left(\mathrm{Na}_{2} \mathrm{~S}_{2} \mathrm{O}_{3}\right.$, STS) is an industrial compound which is typically available as the pentahydrate, $\mathrm{Na}_{2} \mathrm{~S}_{2} \mathrm{O}_{3} \cdot 5 \mathrm{H}_{2} \mathrm{O}$. It also has medical uses in the treatment of some rare medical conditions. These include calciphylaxis in hemodialysis patients with end-stage kidney disease [1] as well as cyanide poisoning [2]. It also has functions as a preservative in table salt (less than $0.1 \%$ ) and alcoholic beverages (less than $0.0005 \%$ ). GMP products are widely available. While these amounts are very small, they indicate that the general population is

\footnotetext{
* Correspondence: mcgeerpl@mail.ubc.ca

Kinsmen Laboratory of Neurological Research, University of British Columbia, 2255 Wesbrook Mall, Vancouver, BC V6T 1Z3, Canada
}

consuming STS on a regular basis and increasing the dose may have important therapeutic applications.

Recently, STS was demonstrated to function as an antiinflammatory agent [3]. For example, in acute liver failure induced in mice by lipopolysaccharide (LPS) or LPS/Dgalactosamine, the survival rate was improved by hydrogen sulfide $\left(\mathrm{H}_{2} \mathrm{~S}\right)$ and STS $[4,5]$. STS is also reported to protect neuronal cells from ischemia [6].

This at least is partially due to the antioxidative function of these two agents; STS reacts with GSSG (oxidized glutathione) to produce reduced glutathione in the presence of hydroxyl radicals or peroxides. In addition, STS has a potential to produce hydrogen sulfide $\left(\mathrm{H}_{2} \mathrm{~S}\right)$ by reaction with trans-sulfuration enzymes [7-10]. 
Previously, we reported that depletion of glutathione (GSH) in glial cells induces neuroinflammation resulting in neuronal death [11]. Neuroinflammation is, at least in part, characterized by the microglial release of proinflammatory factors such as cytokines and free radicals. Its purpose is to remove the source of harm so healing can take place. But when the inflammation is prolonged, it may cause neuronal dysfunction and death [12]. Chronic neuroinflammation is closely associated with the pathogenesis of several neurodegenerative diseases, including Alzheimer's disease (AD) and Parkinson's disease (PD).

In earlier studies, we demonstrated that $\mathrm{H}_{2} \mathrm{~S}$ or $\mathrm{H}_{2} \mathrm{~S}$-releasing moieties, exhibited antioxidative, anti-inflammatory, and neuroprotective properties [13-15]. In this investigation, we studied the effects of sodium hydrosulfide $(\mathrm{NaSH})$ or STS on SH-SY5Y neuronal cell death induced by supernatants from LPS and interferon- $\gamma$ (IFN $\gamma$ )-activated glial cells. These included cultured human astroglial and microglial cells and human THP-1 and U373 cells.

We found that $\mathrm{NaSH}$ and STS generated $\mathrm{H}_{2} \mathrm{~S}$ and $\mathrm{GSH}$ in THP-1 and U373 cells, reduced release of proinflammatory cytokines such as tumor necrosis factor- $\alpha$ (TNF $\alpha)$ and interleukin-6 (IL-6) from LPS/IFN $\gamma$-stimulated microglia and THP-1 cells, as well as IFN $\gamma$-stimulated astrocytes and U373 cells. The toxicity was attenuated in a concentrationdependent and incubation time-dependent manner. This was due to reduced activation of intracellular inflammatory pathways such as P38 MAPK and NFkB proteins.

\section{Methods}

\section{Materials}

All reagents were purchased from Sigma (St. Louis, MO) unless stated otherwise. The following substances were applied to the cell cultures: bacterial LPS (Escherichia coli 055:B5) and human recombinant IFNy (Bachem California, Torrance, CA). Sodium thiosulfate anhydrous (STS) was purchased from Sciencelab.com Inc. (Houston, TX).

\section{Cell culture and experimental protocols}

The human monocyte THP-1 and astrocytoma U373 cell lines were obtained from the American Type Culture Collection (Manassas, VA). The human neuroblastoma SHSY5Y cell line was a gift from Dr R. Ross, Fordham University, NY. These cells were grown in DMEM/F12 medium containing $10 \%$ fetal bovine serum (FBS) and $100 \mathrm{IU} / \mathrm{mL}$ penicillin and $100 \mu \mathrm{g} / \mathrm{mL}$ streptomycin (Invitrogen, Carlsbad, CA) under humidified $5 \% \mathrm{CO}_{2}$ and $95 \%$ air.

Human astroglial and microglial cells were isolated from surgically resected temporal lobe tissue as described previously [15]. Briefly, tissues were rinsed with a phosphatebuffered saline (PBS) solution and chopped into small $\left(<2 \mathrm{~mm}^{3}\right)$ pieces with a sterile scalpel. They were incubated in $10 \mathrm{~mL}$ of a $0.25 \%$ trypsin solution at $37{ }^{\circ} \mathrm{C}$ for 20 min. Subsequently, DNase I (from bovine pancreas,
Pharmacia Biotech, Baie d'Urfé, PQ, Canada) was added to reach a final concentration of $50 \mu \mathrm{g} / \mathrm{mL}$. Tissues were incubated for an additional $10 \mathrm{~min}$ at $37{ }^{\circ} \mathrm{C}$. After centrifugation at $275 \mathrm{~g}$ for $10 \mathrm{~min}$, the cell pellet was resuspended in the serum-containing medium and passed through a $100-\mu \mathrm{m}$ nylon cell strainer (Becton Dickinson, Franklin Lakes, NJ). The cell suspension was then centrifuged ( $275 g$ for $10 \mathrm{~min}$ ), resuspended into $10 \mathrm{~mL}$ of Dulbecco's modified Eagle medium (DMEM)-F12 with $10 \%$ FBS containing gentamicin $(50 \mu \mathrm{g} / \mathrm{mL})$, and plated onto tissue culture plates (Becton Dickinson) in a humidified $5 \% \mathrm{CO}_{2}$, $95 \%$ air atmosphere at $37^{\circ} \mathrm{C}$ for $2 \mathrm{~h}$. This achieved adherence of microglial cells. The non-adherent astrocytes along with myelin debris were transferred into new culture plates. Astrocytes adhered slowly and were allowed to grow by replacing the medium once a week. New passages of cells were generated by harvesting confluent astrocyte cultures using a trypsin-EDTA solution (0.25 \% trypsin with EDTA, Invitrogen, Carlsbad, CA). Human astrocytes from up to the fifth passage from four surgical cases were used in the study.

For estimating the purity of astrocytic and microglial cell cultures, aliquots of the cultures were placed on glass slides at $37{ }^{\circ} \mathrm{C}$ for $48 \mathrm{~h}$. The attached cells were then fixed with $4 \%$ paraformaldehyde for $1 \mathrm{~h}$ at $4{ }^{\circ} \mathrm{C}$ and permeablized with $0.1 \%$ Triton X-100 for $1 \mathrm{~h}$ at room temperature. After washing twice with PBS, the astrocytic culture slides were treated with a monoclonal anti-GFAP antibody $(1 / 4,000$, DAKO) and the microglial slides with the polyclonal antiIba-1 antibody (1/500, Wako Chemicals, Richmond, VA) for $3 \mathrm{~h}$ at room temperature. The slides were then incubated with Alexa Fluor 488-conjugated goat anti-mouse IgG antibody (Invitrogen, 1:500) and Alexa Fluor 546conjugated goat anti-rabbit IgG antibody (Invitrogen, 1:500) in the dark for $3 \mathrm{~h}$ at room temperature to yield red fluorescence for Iba-1 positive cells and green fluorescence for GFAP positive cells. To visualize all cells, the slides were washed twice with PBS. Images were acquired using an Olympus BX51 microscope and a digital camera (Olympus DP71). Fluorescent images were colocalized with ImagePro software (Improvision Inc., Waltham, MA). We randomly chose 30 microscopic fields. Each field contained a total of about 500 cells. The numbers of astrocytes which appeared in microglial culture fields averaged $3.11 \pm 0.12$ cells per field. The numbers of microglia appearing in astrocytic culture fields was $2.05 \pm 0.34$ cells per field. The purity of microglia and astrocytic cultures was more than $99 \%$ (Fig. 1).

To achieve SH-SY5Y differentiation, the undifferentiated cells were treated for 4 days with a high concentration of retinoic acid (RA, $5 \mu \mathrm{M})$ in DMEM/F12 medium containing $5 \% \mathrm{FBS}, 100 \mathrm{IU} / \mathrm{mL}$ penicillin, and $100 \mu \mathrm{g} / \mathrm{mL}$ streptomycin [16]. The RA-including medium was changed every 2 days. Differentiated SH-SY5Y cells demonstrated neurite 

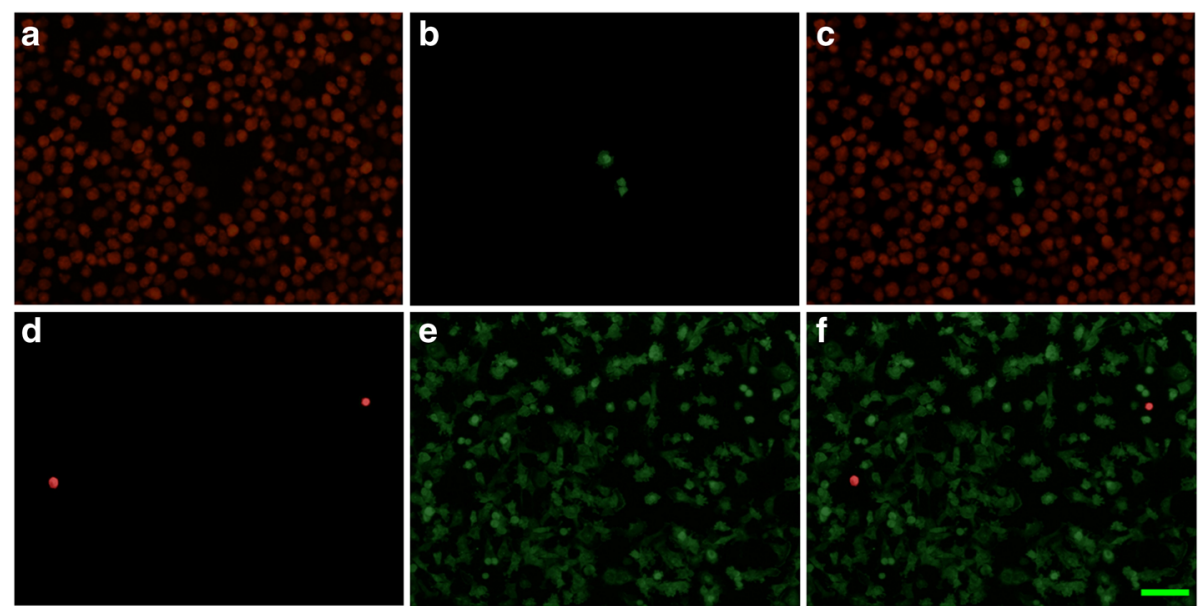

Fig. $1 \mathrm{Imm}$ Inofluorescence staining of Iba-1 (a, $\mathbf{d}$ red) in microglia and GFAP (b, e green) and merged images (c, $\mathbf{f})$ in astrocytes in the microglia $(\mathbf{a}-\mathbf{c})$ and astrocytic cultures $(\mathbf{d}-\mathbf{f})$. The results suggested that more than $99 \%$ of cells prepared from human brains are microglia and astrocytes, respectively. The calibration bar in F: $50 \mu \mathrm{m}$

extension, indicative of their differentiation [17], and act like a fully-differentiated human neuron-like cells [18].

\section{Experimental protocols \\ Protocol 1}

Human astrocytes, U373 astrocytoma cells and THP-1 cells $\left(5 \times 10^{5}\right.$ cells), and human microglial cells $\left(5 \times 10^{4}\right.$ cells) were seeded into 24-well plates in $1 \mathrm{~mL}$ of DMEM/ F12 medium containing $5 \%$ FBS. NaSH or STS was then introduced at concentrations of 1 to $500 \mu \mathrm{M}$ (the stock solutions were prepared just before use with sterilized deionized water). Incubation of the mixtures was carried out for 2, 4, 8, or $12 \mathrm{~h}$. Cells were washed with PBS twice and replated in $800 \mu \mathrm{L}$ DMEM/F12 medium containing $5 \%$ FBS. One set of cells was then incubated at $37^{\circ} \mathrm{C}$ for 2 days in the presence of inflammatory stimulants. For microglia and THP- 1 cells, the stimulants were LPS at $1 \mu \mathrm{g} / \mathrm{mL}$ and IFNY at $333 \mathrm{U} / \mathrm{mL}$. For astrocytes and U373 cells, the stimulant was IFN $\gamma$ alone at $150 \mathrm{U} / \mathrm{mL}$. A comparable set of cells was incubated in media without inflammatory stimulants. After incubation, the supernatants $(400 \mu \mathrm{L})$ were transferred to differentiated human neuroblastoma SH-SY5Y cells $\left(2 \times 10^{5}\right.$ cells per well). The cells were incubated for a further $72 \mathrm{~h}$ and 3-(4,5-dimethylthiazol-2-yl)2,5-diphenyl tetrazolium bromide (MTT) assays were performed as described below.

\section{Protocol 2}

Since it is perceived that both $\mathrm{NaSH}$ and STS could be useful as pharmaceutical agents, they must be shown to be nontoxic to humans. To determine whether they were directly affecting SH-SY5Y cell viability in the presence of LPS/IFN $\gamma$-stimulated THP-1 conditioned medium (CM) or IFNy-stimulated U373 CM, NaSH or STS was added to a glial cell supernatant $(400 \mu \mathrm{L})$ just before the supernatants were added to the SH-SY5Y cells. The glial cell supernatants were from THP-1 cells or U373 cells that had been activated for 2 days with the inflammatory stimulants previously described. The subsequent procedures were the same as in protocol 1.

\section{SH-SY5Y cell viability assays}

The viability of SH-SY5Y cells following incubation with glial cell supernatants was evaluated by MTT assays as previously described [19]. Briefly, the viability was determined by adding MTT to the SH-SY5Y cell cultures to reach a final concentration of $1 \mathrm{mg} / \mathrm{mL}$. Following a $1 \mathrm{~h}$ incubation at $37{ }^{\circ} \mathrm{C}$, the dark crystals formed were dissolved by adding a SDS/DMF extraction buffer $(300 \mu \mathrm{L}$, $20 \%$ sodium dodecyl sulfate, $50 \% \mathrm{~N}, \mathrm{~N}$-dimethylformamide, $\mathrm{pH}$ 4.7). Subsequently, plates were incubated overnight at $37{ }^{\circ} \mathrm{C}$, and optical densities at $570 \mathrm{~nm}$ were measured by transferring $100 \mu \mathrm{L}$ aliquots to 96 -well plates and using a plate reader with a corresponding filter. Data are presented as a percentage of the values obtained from cells incubated in fresh medium only.

The viability of differentiated SH-SY5Y cells was investigated by the lactate dehydrogenase (LDH) release assay [19]. Briefly, cell culture supernatants $(100 \mu \mathrm{l})$ were pipetted into the wells of 96-well plates, followed by the addition of $15 \mu$ l lactate solution $(36 \mathrm{mg} / \mathrm{ml}$ in PBS) and $15 \mu \mathrm{l}$-iodonitrotetrazolium violet (INT) solution $(2 \mathrm{mg} /$ $\mathrm{ml}$ in PBS). The enzymatic reaction was started by addition of $15 \mu \mathrm{l}$ of $\mathrm{NAD}^{+} /$diaphorase solution $(3 \mathrm{mg} / \mathrm{ml}$ $\mathrm{NAD}^{+} ; 2.3 \mathrm{mg}$ solid/ml diaphorase). After $1 \mathrm{~h}$, optical densities were measured with a Model 450 microplate reader (Bio-Rad Laboratories, Richmond, CA) using a 490-nm filter. The amount of LDH released was expressed 
as a percentage of the value obtained in comparative wells where cells were $100 \%$ lysed by $1 \%$ Triton X-100.

\section{Measurement of TNFa and IL- 6 release}

Cytokine levels were measured in cell-free supernatants following $48 \mathrm{~h}$ incubation of THP-1 cells, U373 cells, microglial cells, and astrocytes. The cell stimulation protocols in these experiments were the same as that used in protocol 1. Quantitation was performed with ELISA detection kits (Peprotech, NJ) following protocols described by the manufacturer.

For determining TNF $\alpha$ and IL-6 depletion, protocols published in earlier studies were followed $[17,20]$. Briefly, microglia were exposed to LPS/IFN $\gamma$, and astrocytes to IFN $\gamma$, for 2 days. Their supernatants were transferred to 24-well plates which had been coated with anti-TNF $\alpha$ or anti-IL-6 antibodies (10 mg/ml). After 3-h incubation, the supernatants were transferred to SH-SY5Y cells. After incubation at $37{ }^{\circ} \mathrm{C}$ for 3 days, MTT assays were performed on the SH-SY5Y cells.

\section{Activation of P38 MAPK and NFKB protein by Western Blotting}

Western blotting on cell lysates was performed as described previously [19]. Briefly, microglia and astrocytes were exposed to $\mathrm{NaSH}$ and STS at $100 \mu \mathrm{M}$ for $8 \mathrm{~h}$ and were subsequently exposed to stimulants for $2 \mathrm{~h}$. Human microglia and astrocytes were treated with a lysis buffer $(150 \mathrm{~mm} \mathrm{NaCl}, 12 \mathrm{~mm}$ deoxycholic acid, $0.1 \%$ Nonidet P-40, $0.1 \%$ Triton X-100, and 5 mm Tris-EDTA, pH 7.4). The protein concentration of the cell lysates was then determined using a BCA protein assay reagent kit (Pierce, Rockford, IL). Proteins in each sample were loaded onto gels and separated by $10 \%$ sodium dodecyl sulfate polyacrylamide gel electrophoresis (SDS-PAGE) (150 V, $1.5 \mathrm{~h}$ ). The loading quantities of lysate proteins were $100 \mu$ g. Following SDS-PAGE, proteins were transferred to a PVDF membrane (Bio-Rad, CA) at $30 \mathrm{~mA}$ for $2 \mathrm{~h}$. The membranes were blocked with $5 \%$ milk in PBS-T $(80 \mathrm{~mm}$ $\mathrm{Na}_{2} \mathrm{HPO}_{4}, 20 \mathrm{~mm} \mathrm{NaH} \mathrm{PO}_{4}, 100 \mathrm{~mm} \mathrm{NaCl}, 0.1$ \% Tween 20, pH 7.4) for $1 \mathrm{~h}$ and incubated overnight at $4{ }^{\circ} \mathrm{C}$ with a polyclonal anti-phospho-P38 MAP kinase antibody (9211, Cell Signaling, Beverly, MA, 1/2,000) or anti-phospho-P65 NFKB antibody (3031, Cell Signaling, 1/1,000). The membranes were then treated with a horseradish peroxidaseconjugated anti-IgG (P0448, DAKO, Mississauga, Ontario, CA, 1:2,000) or the secondary antibody anti-mouse IgG (A3682, Sigma, 1/3,000) for $3 \mathrm{~h}$ at room temperature, and the bands were visualized with an enhanced chemiluminescence system and exposure to photographic film (Hyperfilm ECL ${ }^{\mathrm{Tm}}$, Amersham Biosciences). Equalization of protein loading was assessed independently using $\alpha$ tubulin as the housekeeping protein. The primary antibody was anti- $\alpha$-tubulin (T6074, Sigma, 1/2,000) and the secondary antibody anti-mouse IgG (A3682, Sigma, 1/ 3,000 ). Primary antibody incubation was overnight at $4{ }^{\circ} \mathrm{C}$, and the secondary antibody incubation was for $3 \mathrm{~h}$ at room temperature.

\section{Measurement of $\mathrm{H}_{2} \mathrm{~S}$ Levels}

$\mathrm{H}_{2} \mathrm{~S}$ (HS ${ }^{-}$) levels were measured using a previously described method [15]. To suppress endogenous production of $\mathrm{H}_{2} \mathrm{~S}$ by $\mathrm{CBS}$, all experiments were done with $0.1 \mathrm{mM}$ of the specific CBS inhibitor hydroxylamine added to the solutions. Two sets of experiments were conducted: one in which the THP-1 cells and U373 cells were unstimulated and a second where they were stimulated with inflammatory mediators for $48 \mathrm{~h}$. For THP-1 cells, the stimulation was LPS at $1 \mu \mathrm{g} / \mathrm{ml}$ and IFN $\gamma$ at $333 \mathrm{U} / \mathrm{ml}$, and for U373 cells, it was IFN $\gamma$ at $150 \mathrm{U} / \mathrm{ml}$. The cells in each case were treated with hydroxylamine plus $\mathrm{NaSH}$ or hydroxylamine plus STS (100 $\mu \mathrm{M}$ each) for 2, 4, 8, and $12 \mathrm{~h}$. Following treatment, they were homogenized in $250 \mu \mathrm{l}$ of ice-cold $100 \mathrm{mM}$ potassium phosphate buffer ( $\mathrm{pH}$ 7.4) containing trichloroacetic acid $(10 \% \mathrm{w} / \mathrm{v})$. Zinc acetate $(1 \% \mathrm{w} / \mathrm{v}$, $250 \mu \mathrm{l}$ ) was injected to trap the generated $\mathrm{H}_{2} \mathrm{~S}$. A solution of $N, N$-dimethyl-p-phenylenediamine sulfate $(20 \mu \mathrm{M}$; $133 \mu \mathrm{l})$ in $7.2 \mathrm{~m} \mathrm{HCl}$ and $\mathrm{FeCl}_{3}(30 \mu \mathrm{M} ; 133 \mu \mathrm{l})$ in $1.2 \mathrm{M}$ $\mathrm{HCl}$ was added. Absorbance at $670 \mathrm{~nm}$ of the resulting mixture $(300 \mu \mathrm{l})$ was determined after 10 min using a 96well microplate reader (Bio- $\mathrm{Rad}$ ). The $\mathrm{H}_{2} \mathrm{~S}$ concentration of each sample was calculated against a calibration curve of $\mathrm{NaSH}(1-500 \mu \mathrm{mol} / \mathrm{ml})$. The protein concentration was measured with a BCA protein assay reagent kit (Pierce, Rockford, IL). The concentrations were expressed as micromole per gram protein.

\section{Glutathione level}

The GSH level was assessed by the method of Hissin and Hilf [21] and Lee et al. [11]. This assay detects reduced GSH by its reaction with $o$-phthalaldehyde (OPT) at $\mathrm{pH}$ 8.0. Cells $\left(10^{6}\right)$ in $1.5-\mathrm{ml}$ tubes were washed twice with PBS, and $200 \mu \mathrm{l}$ of $6.5 \%$ trichloroacetic acid (TCA) was added. The mixture was incubated on ice for $10 \mathrm{~min}$ and centrifuged (13,000 rpm, $1 \mathrm{~min})$. The supernatant was discarded, and the pellets were resuspended in $200 \mu \mathrm{l}$ of icecold $6.5 \%$ TCA and centrifuged again $(13,000 \mathrm{rpm}$, $2 \mathrm{~min})$. Supernatants $(7.5 \mu \mathrm{l})$ were transferred to 96-well plates containing $277.5 \mu \mathrm{l}$ phosphate-EDTA buffer $(\mathrm{pH}$ $8.0)$ in $1 \mathrm{M} \mathrm{NaOH}$ solution. Then, $15 \mu \mathrm{lOPT}(1 \mathrm{mg} / \mathrm{ml}$ in methanol) was added. The reaction mixture was incubated in the dark at room temperature for $25 \mathrm{~min}$. The fluorescence at $350 \mathrm{~nm}$ excitation/420 nm emission was measured in a multiwell plate reader. The concentration was calculated from a standard curve using serial dilutions of reduced GSH. The concentration was expressed as micromole per gram protein. 


\section{Data analysis}

The significance of differences between data sets was analyzed by one-way or two-way ANOVA tests. Multiple group comparisons were followed by a post hoc Bonferroni test. $P$ values are given in the figure legends.

\section{Results}

In these experiments, we compared $\mathrm{NaSH}$ with sodium thiosulfate (STS). We firstly measured $\mathrm{H}_{2} \mathrm{~S}\left(\mathrm{SH}^{-}\right)$and GSH levels in THP-1 and U373 cells after treatment with STS or NaSH. These cells are regarded as surrogate cells of microglia and astrocytes. Intracellular $\mathrm{H}_{2} \mathrm{~S}\left(\mathrm{SH}^{-}\right)$and GSH concentrations were measured after treatment with LPS/IFNy for THP-1 cells and IFNy for U373 cells (100 $\mu \mathrm{M}$ each). STS and NaSH were exposed to the cells for $0,2,4,8$, and $12 \mathrm{~h}$. The results are shown in Fig. 2. In both cell types, the $\mathrm{H}_{2} \mathrm{~S}\left(\mathrm{SH}^{-}\right)$and $\mathrm{GSH}$ content increased in an incubation time-dependent manner. However, the levels were dramatically decreased when THP-1 cells were exposed to LPS/IFN $\gamma$, and U373 cells to IFN $\gamma$, for 2 days. For the NaSH groups, LPS/IFN $\gamma$ treatment reduced both $\mathrm{H}_{2} \mathrm{~S}$ and GSH content in THP-1 cells by $75 \%$ after $12 \mathrm{~h}$.
IFNy treatment reduced $\mathrm{H}_{2} \mathrm{~S}$ and $\mathrm{GSH}$ by 80 and $85 \%$, respectively, in U373 cells after $12 \mathrm{~h}$. For STS groups, LPS/ IFN $\gamma$ treatment reduced $\mathrm{H}_{2} \mathrm{~S}$ and $\mathrm{GSH}$ by 75 and $90 \%$, respectively, in THP-1 cells after in $12 \mathrm{~h}$, and IFNy treatment reduced by $80 \%$ in $\mathrm{H}_{2} \mathrm{~S}$ and by $90 \%$ in $\mathrm{GSH}$ in U373 cells after $12 \mathrm{~h}$. NaSH generated somewhat more $\mathrm{H}_{2} \mathrm{~S}\left(\mathrm{SH}^{-}\right)$and $\mathrm{GSH}$ than STS in both unstimulated and stimulated cells. The data indicate that $12 \mathrm{~h}$ after $\mathrm{NaSH}$ or STS treatment, substantial amounts of $\mathrm{H}_{2} \mathrm{~S}\left(\mathrm{SH}^{-}\right)$and GSH were still found in both types of cells after 2 days. Therefore, we chose 2, 4, 8, and $12 \mathrm{~h}$ incubation time periods for further experiments.

\section{Release of inflammatory cytokines}

Inflammatory stimulation of microglia or THP-1 cells causes them to release the inflammatory cytokines TNF $\alpha$ and IL-6 $[22,23]$. Figure 3 shows the effect on TNF $\alpha$ release by treatment of glial cells with $\mathrm{NaSH}$ and STS (1$500 \mu \mathrm{M}$ for $8 \mathrm{~h}$ pre-incubation, protocol 1). THP-1 release of TNF $\alpha$ (Fig. 3a) and IL-6 (Fig. 3b) and human microglial release of TNF $\alpha$ (Fig. 3c) and IL-6 (Fig. 3d) are illustrated. The release of TNF $\alpha$ (Fig. 3a) and IL-6 (Fig. 3b) was

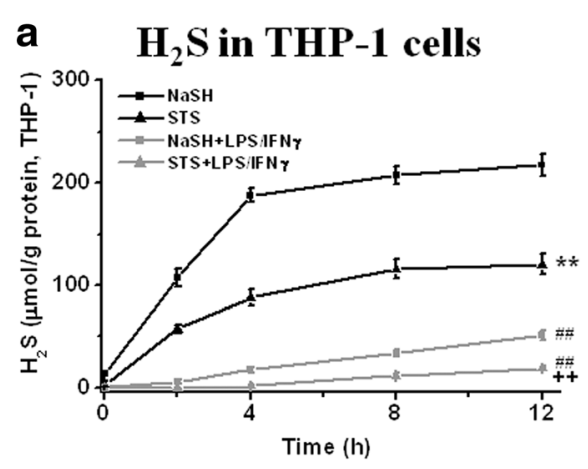

c GSH in THP-1 cells

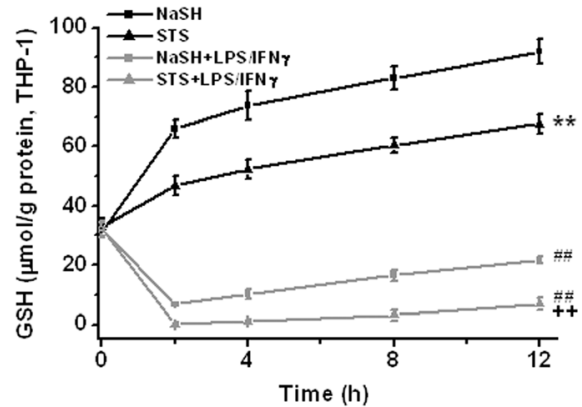

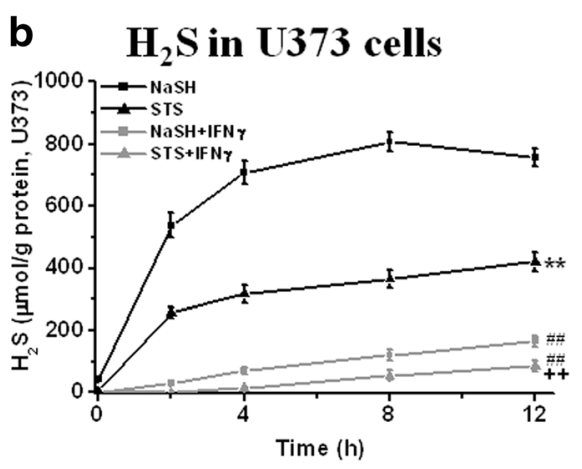

d GSH in U373 cells

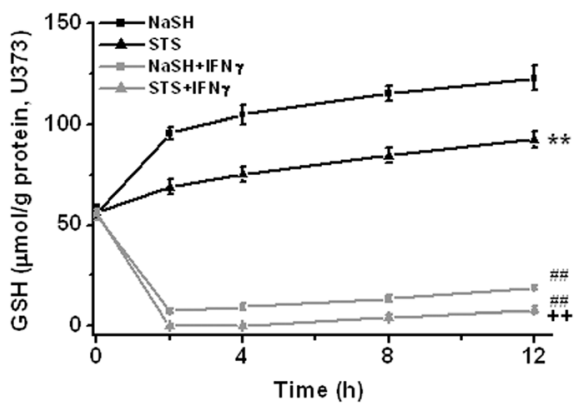

Fig. 2 Intracellular $\mathrm{H}_{2} \mathrm{~S}\left(\mathrm{SH}^{-}\right)$and GSH concentrations produced from NaSH and STS in THP-1 cells (a, c) and U373 cells (b, d) with or without stimulation for 2 days (for THP-1 cells: LPS/IFNY and for U373 cells: IFNY). NaSH and STS (100 $\mu$ M each) were separately added to THP-1 cells. See "Methods" section for details. Values are mean \pm SEM, $n=4$. Two-way ANOVA was carried out to test significance. Multiple comparisons were followed with post hoc Bonferroni tests. $\mathbf{a}-\mathbf{d}{ }^{* *} P<0.01$ for STS-treated groups compared with NaSH groups in the same condition (without stimulants) between 2 and $12 \mathrm{~h},{ }^{\# \#} P<0.01$ for LPS/IFNy- or IFNy-activated groups compared with groups without stimulants between 2 and 12 h, ${ }^{++} P<0.01$ for STS-treated groups compared with NaSH groups in the presence of stimulants between 2 and 12 h. Activation of both cells with stimulants dramatically reduced $\mathrm{H}_{2} \mathrm{~S}$ and GSH. NaSH was a somewhat more powerful agent than STS, but there was no qualitative difference between the two agents 

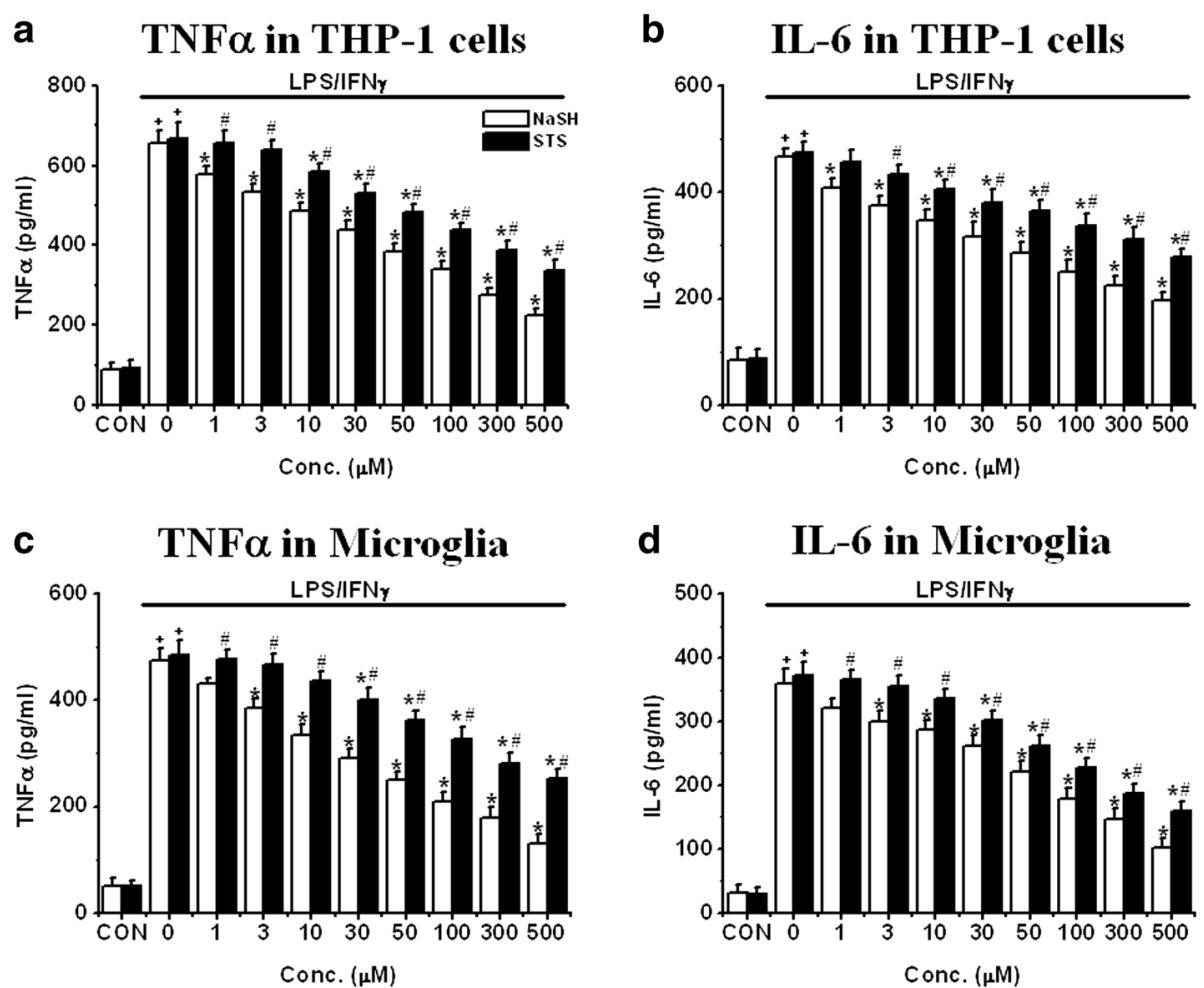

Fig. 3 Effect of pre-treatment with NaSH or STS on released levels of TNFa $(\mathbf{a}, \mathbf{c})$ or IL-6 (b, d) from LPS/IFNy-activated THP-1 cells (a, b) or LPS/ IFNY-activated microglia $(\mathbf{c}, \mathbf{d}) .8 \mathrm{~h}$ pre-incubation with NaSH or STS was performed before LPS/IFNY was exposed to the cells for 2 days. Values are mean \pm SEM, $n=4$. $\mathbf{a}$, $\mathbf{b}$ Two-way ANOVA was carried out to test significance. Multiple comparisons were followed with post hoc Bonferroni tests. ${ }^{+} P<0.01$ for LPS/IFNY-activated groups compared with control (CON) groups in each condition, ${ }^{*} P<0.01$ for NaSH- or STS-treated groups compared with LPS/FNY-activated groups, ${ }^{\#} P<0.01$ for STS-treated groups compared with NaSH groups in each condition. Note that both compounds attenuated released levels of TNFa and IL-6 from both cell types in a concentration-dependent manner

reduced by $\mathrm{NaSH}$ and STS exposure in a concentrationdependent manner (Fig. 3, NaSH: $P<0.01$ for $1 \mu \mathrm{M}$ or higher and for STS: $P<0.01$ for $10 \mu \mathrm{M}$ or higher). The inhibitory effects of $\mathrm{NaSH}$ were more powerful than STS $(P$ $<0.01$ for $1 \mu \mathrm{M}$ or higher and for TNF $\alpha$ and $P<0.01$ for 3 $\mu \mathrm{M}$ or higher for IL-6). The $\mathrm{IC}_{50}$ values for $\mathrm{NaSH}$ and STS shown in Table 1 (A, B) were confirmatory. The pattern was similar in microglia (Fig. 3c, d). LPS/IFNY stimulation caused a 9.5-fold increase of TNF $\alpha$ and an 11-fold increase of IL-6. Treatment with $\mathrm{NaSH}$ and STS reduced this release (NaSH: $75 \%$ and STS: $50-60 \%$ at $500 \mu \mathrm{M}, P<0.01$ ).

For astrocytes, IL-6 is the main inflammatory mediator that is generated [24]. Figure 4 shows comparable data for IL-6 release from U373 cells (Fig. 4a) and cultured astrocytes (Fig. 4b). Cells were activated with IFNY according to experimental protocol 1 and were then treated similarly to the THP-1 and microglial cells shown in Fig. 3. The release of IL- 6 was more than fourfold higher in primary cultured astrocytes compared with U373 cells. However, both compounds reduced the release of IL-6 from IFN $\gamma$ activated U373 cells or astrocytes in a concentrationdependent manner $(P<0.01 \mathrm{NaSH}: P<0.01$ from $1 \mu \mathrm{M}$ and for STS: $P<0.01$ from $10 \mu \mathrm{M})$. Again, $\mathrm{NaSH}$ is stronger in reducing IL-6 release in both cell types $(P<$ 0.01 from $1 \mu \mathrm{M})$. The $\mathrm{IC}_{50}$ values for $\mathrm{NaSH}$ and STS are shown in Table $1(\mathrm{C})$. NaSH is more potent than STS in attenuating release of these cytokines.

We investigated, as described in methods, the direct effects of TNF $\alpha$ and IL- 6 treatment, alone and in combination, on the viability of SH-SY5Y cells. MTT assays were performed after 3 days incubation at $37^{\circ} \mathrm{C}$. There were no changes in viability as shown in Fig. 5. However, the effects were different when the cells were exposed to cytokine-depleted CM from microglia and astrocytes. For depleted microglial conditioned medium $(\mathrm{CM})$, the $\mathrm{SH}$ SY5Y viability was increased by $10.6 \%$ for TNFa, $8.7 \%$ for IL-6, and $21 \%$ for TNF $\alpha+$ IL-6 (Fig. 5a). For astrocytes, the corresponding increase in viability for IL-6 depletion was $22 \%$ (Fig. 5b).

\section{Neuroprotective effect of $\mathrm{NaSH}$ and STS against} microglial, astrocytic, THP-1, and U373 cell toxicity We investigated the effects of pre-treatment with $\mathrm{NaSH}$ and STS on the toxicity of CM toward SH-SY5Y cells. The $\mathrm{CM}$ was obtained by 2 days treatment of LPS/IFNY- 
Table $1 \mathrm{IC}_{50}(\mu \mathrm{M})$ based on stimulated glial cell-released TNFa and IL-6 data of NaSH and STS at $8 \mathrm{~h}$ pre-incubation times

\begin{tabular}{|c|c|c|c|c|}
\hline \multicolumn{5}{|c|}{ (A) TNFa: THP-1 cells and microglia } \\
\hline \multirow[b]{2}{*}{ Pre-incubation time } & \multicolumn{2}{|l|}{ THP-1 cells } & \multicolumn{2}{|l|}{ Microglia } \\
\hline & $\mathrm{NaSH}$ & STS & $\mathrm{NaSH}$ & STS \\
\hline $8 \mathrm{~h}$ & $31.15 \pm 3.66$ & $424.53 \pm 18.25^{*}$ & $26.71 \pm 4.32$ & $579.53 \pm 27.75^{*}$ \\
\hline \multicolumn{5}{|c|}{ (B) IL-6: THP-1 cells and microglia } \\
\hline & THP-1 cells & & Microglia & \\
\hline Pre-incubation time & $\mathrm{NaSH}$ & STS & $\mathrm{NaSH}$ & STS \\
\hline $8 \mathrm{~h}$ & $63.84 \pm 7.95$ & $621.53 \pm 24.25^{*}$ & $33.36 \pm 5.32$ & $87.28 \pm 6.79^{*}$ \\
\hline \multicolumn{5}{|c|}{ (C) IL-6: U373 cells and astrocytes } \\
\hline & U373 cells & & Astrocytes & \\
\hline Pre-incubation time & $\mathrm{NaSH}$ & STS & $\mathrm{NaSH}$ & STS \\
\hline $8 \mathrm{~h}$ & $432.26 \pm 54.14$ & $1356.53 \pm 224.25^{*}$ & $7.44 \pm 0.87$ & $102.79 \pm 11.25^{*}$ \\
\hline
\end{tabular}

The tables summarized the $I_{50}$ results of the studies in Fig. 3 (Table $1(\mathrm{~A}, \mathrm{~B})$ ) and Fig. 4 (Table $1(\mathrm{C})$ ). Values are mean $\pm \mathrm{SEM}, n=4$. One-way ANOVA was carried out to test significance. Note that there was a significant reduction in $\mathrm{IC}_{50}$ values of $\mathrm{NaSH}$ compared with those of STS in all groups ${ }^{*} P<0.01$

activated THP-1 cells and IFNy-activated U373 cells. Experimental protocol 1 was followed.

It was found that $\mathrm{NaSH}$ and STS each attenuated $\mathrm{SH}-$ SY5Y cell viability loss by THP-1 CM (Fig. 6). The effect was concentration-dependent in the $1-500 \mu \mathrm{M}$ range and was time-dependent up to $12 \mathrm{~h}$ (Fig. 6a: $2 \mathrm{~h}$ preincubation, $6 \mathrm{~b}: 4 \mathrm{~h}$ pre-incubation, $6 \mathrm{c}: 8 \mathrm{~h}$ pre-incubation and $6 \mathrm{~d}: 12 \mathrm{~h}$ pre-incubation). At the shortest time interval of $2 \mathrm{~h}$ and at the lowest concentration of $1 \mu \mathrm{M}$, the protective effect of $\mathrm{NaSH}$ was minimal. But the toxicity was reduced to about half at a concentration of $500 \mu \mathrm{M}(P<$ 0.01 from $1 \mu \mathrm{M})$. By $12 \mathrm{~h}$ the protective effect had increased to the point where the lowest concentration reduced the toxicity by about one third while the highest concentration reduced it by about five- to sixfold. Pre- treatment with STS also attenuated THP-1 toxicity toward SH-SY5Y cells at $2 \mathrm{~h}$ pre-incubation $(P<0.01$ from $50 \mu \mathrm{M})$ but was less effective than $\mathrm{NaSH}(P<0.01$ from $3 \mu \mathrm{M}$ ); protective levels were $75 \%$ of those obtained with $\mathrm{NaSH}$.

Figure 7 shows the effects of exposing SH-SY5Y cells to the neurotoxic CM from U373 cells that had been stimulated with $150 \mathrm{U}$ of IFN $\gamma$ according to experimental protocol 1 . The figure shows highly similar data to those obtained from stimulated THP-1 cells (Fig. 7a: $2 \mathrm{~h}$ preincubation, 7b: $4 \mathrm{~h}$ pre-incubation, 7c: $8 \mathrm{~h}$ pre-incubation and $7 \mathrm{~d}: 12 \mathrm{~h}$ pre-incubation) were obtained. Again, the protective effect of the both agents was both concentrationdependent and incubation time-dependent. $\mathrm{NaSH}$ was more neuroprotective than STS (MTT test data: $P<0.01$
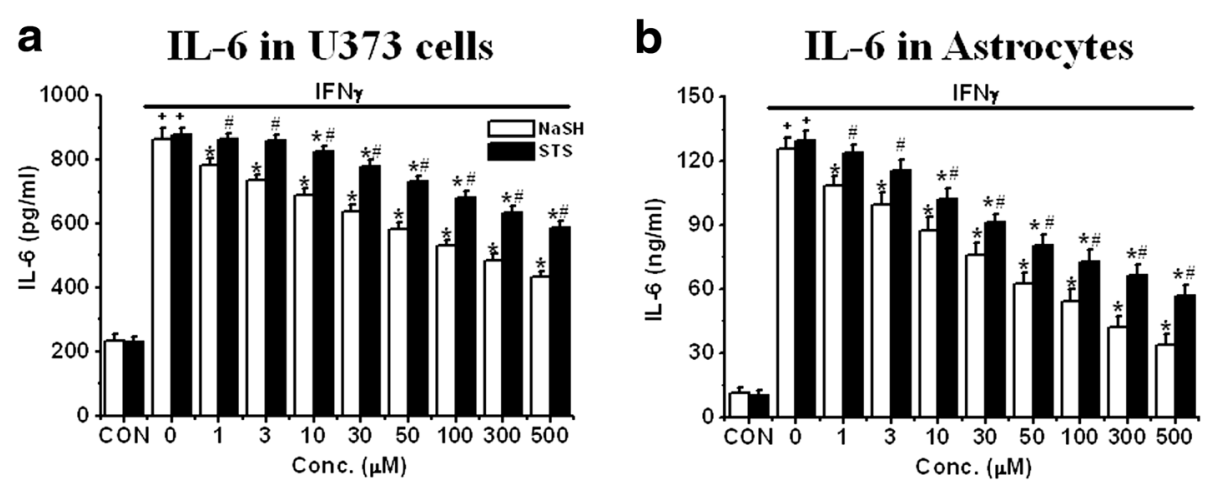

Fig. 4 Effect of pre-treatment with NaSH or STS on released levels of IL-6 from IFNY-activated U373 cells (a) or IFNY-activated astrocytes (b). 8 h pre-incubation with $\mathrm{NaSH}$ or STS was performed before IFNy was exposed to the cells for 2 days. Values are mean \pm SEM, $n=4$. $\mathbf{a}, \mathbf{b}$ Two-way ANOVA was carried out to test significance. Multiple comparisons were followed with post hoc Bonferroni tests. ${ }^{+} P<0.01$ for LPS/IFNY-activated groups compared with CON groups for each condition, ${ }^{*} P<0.01$ for NaSH- or STS-treated groups compared with LPS/IFNY-activated groups, ${ }^{\#} P<0.01$ for STS-treated groups compared with NaSH groups in each conditions. Note that both compounds attenuated released levels of IL- 6 from both cell types in a concentration-dependent manner 

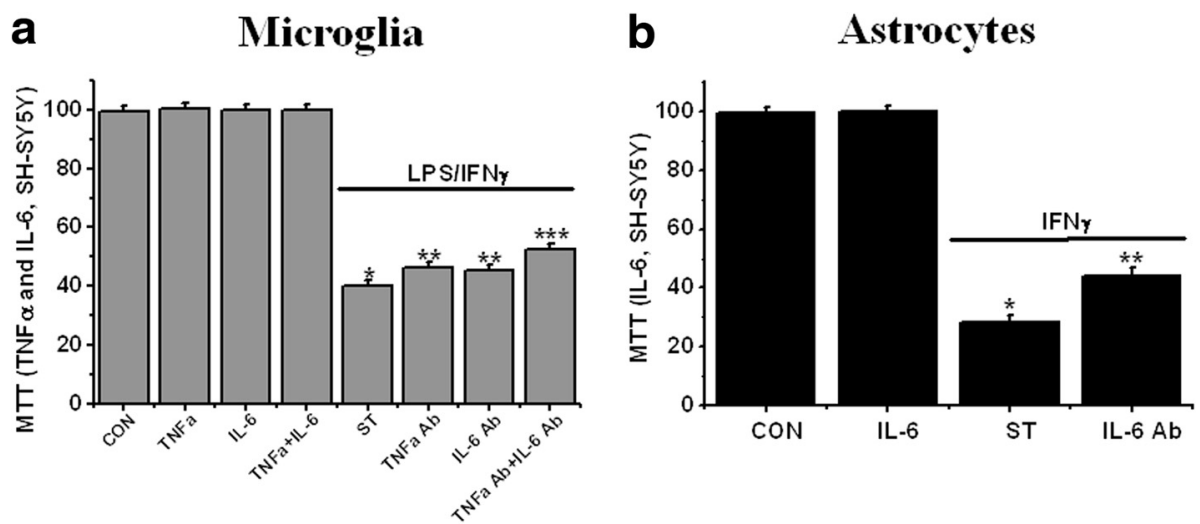

Fig. 5 a Contribution of TNFa and IL-6 released from LPS/IFNY-stimulated microglia on SH-5Y5Y cell viability. Direct treatment of RA-differentiated SH-SY5Y cells with TNFa $(800 \mathrm{pg} / \mathrm{ml})$ and/or IL-6 $(600 \mathrm{pg} / \mathrm{ml})$ was not changed SH-SY5Y cell viability (TNFa, IL-6, and TNFa + IL-6 in $x$-axis). Effects of removing TNFa and/or IL-6 using their specific antibody (ELISA methods) from neurotoxic secretions from microglia stimulated with LPS/IFNY (TNFa Ab, IL-6 Ab, and TNFa Ab + IL-6 Ab in x-axis). CON and ST mean unstimulation and stimulation, respectively. See "Methods" section for details. One-way ANOVA was carried out to test significance. ${ }^{*} P<0.01$ vs CON group, ${ }^{* *} P<0.01$ vs ST group, and ${ }^{* *} P<0.01$ vs TNFa Ab and IL-6 Ab groups. b Contribution of IL-6 released from IFNY-stimulated astrocytes on SH-5Y5Y cell viability. For details, see "Methods" section. Direct treatment of RAdifferentiated SH-SY5Y cells with IL-6 $(120 \mathrm{ng} / \mathrm{ml})$ was not changed SH-SY5Y cell viability (IL-6 in $x$-axis). Effects of removing IL-6 using their specific antibody (ELISA methods) from neurotoxic secretions from astrocytes stimulated with IFNY (IL-6 Ab in $x$-axis). CON and ST mean unstimulation and stimulation, respectively. See "Methods" section for details. One-way ANOVA was carried out to test significance. ${ }^{*} P<0.01$ vs CON group and **P<0.01 vs ST group

from $50 \mu \mathrm{M}$ at $2 \mathrm{~h}, P<0.01$ from $30 \mu \mathrm{M}$ at $4 \mathrm{~h}, P<0.01$ from $10 \mu \mathrm{M}$ at $8 \mathrm{~h}, P<0.01$ from $3 \mu \mathrm{M}$ at $12 \mathrm{~h}$ ).

Table 2 summarized the $\mathrm{IC}_{50}$ results of these studies. As shown in Figs. 6 and 7, the concentrations of $\mathrm{NaSH}$ required to reach the level of $\mathrm{IC}_{50}$, for both THP-1 and U373 cells, are approximately threefold lower than those required for STS at all the incubation times in both THP-1 and U373 cells. The data indicate that $\mathrm{IC}_{50} \mathrm{~s}$ of $\mathrm{NaSH}$ and STS are reduced with a longer pre-incubation time. $\mathrm{The}^{\mathrm{I}} \mathrm{C}_{50} \mathrm{~S}$ of $\mathrm{NaSH}$ were at least three times lower than those of STS in each pre-incubation time in both cell types.

We also investigated the effect of supernatants from LPS/IFN $\gamma$-stimulated microglia and IFN $\gamma$-stimulated astrocytes on SH-SY5Y cell viability after treatment with all the agents. Due to the limited availability of microglia and astrocytes, they were pre-exposed to the compounds at only one time period $(8 \mathrm{~h})$ prior to treatment with stimulatory agents (experimental protocol 1). For measuring SH-SY5Y cell viability, the MTT and LDH release assays were utilized (upper panel: MTT assays and lower panel: LDH release assays). It was observed that both $\mathrm{NaSH}$ and STS reduced the toxicity of both LPS/IFNYstimulated microglia (Fig. 8a) and IFN $\gamma$-stimulated astrocytes (Fig. 8b) toward SH-SY5Y cells (MTT assay data: for NaSH: $P<0.01$ from $1 \mu \mathrm{M}$ and for STS: $P<0.01$ from $10 \mu \mathrm{M})$. Again, $\mathrm{NaSH}$ had a greater neuroprotective effect than STS (MTT assay data: $P<0.01$ from $1 \mu \mathrm{M})$ (Table 3). These data demonstrate that the effects observed with cultured microglia and astrocytes are comparable to those observed with the THP-1 and U373 cell lines.
However, pre-treatment with NaSH or STS of THP-1 cells and U373 cells for $12 \mathrm{~h}$ and of microglia and astrocytes for $8 \mathrm{~h}$ with both compounds did not change the viability of any glial cells by stimulants (LPS/IFNY for THP-1 cells and microglia: Additional file 1: Figure S1A and S1C, and IFNY for U373 cells and strocytes: Additional file 1: Figure S1B and S1D).

It was also found that $\mathrm{NaSH}$ and STS were not directly protective of SH-SY5Y cells (Additional file 1: Figure S2). When they were added to the CM after stimulation had taken place (protocol 2, A: THP-1 cells and B: U373 cells), they had no effect. As the figure shows, there was no difference between the agents and there was no effect of concentration. This establishes that the agents were working by inhibiting the glial inflammatory response.

In summary, $\mathrm{NaSH}$ and STS were not toxic to the glial cells in the presence of inflammatory stimuli. The viability of SH-SY5Y cells treated with the CM from LPS/IFNYstimulated THP-1 and IFN $\gamma$-stimulated U373 cells was unchanged.

As further control experiments, we tested the effects of $\mathrm{NaSH}$ and STS on the growth and survival of human microglia and astrocytes under normal and inflammatory conditions. Human microglia and astrocytes were treated with NaSH or STS for 3 days. MTT assays were then performed on the cultures. Microglia and astrocytes were next treated with stimulants plus $\mathrm{NaSH}$ or STS for 2 days. The stimulants were LPS/IFN $\gamma$ for microglia and IFN $\gamma$ for astrocytes. Comparative MTT assays were then performed on the cultures. The results are shown in Additional file 1: Figure S3. It was found that STS and $\mathrm{NaSH}$ did not 

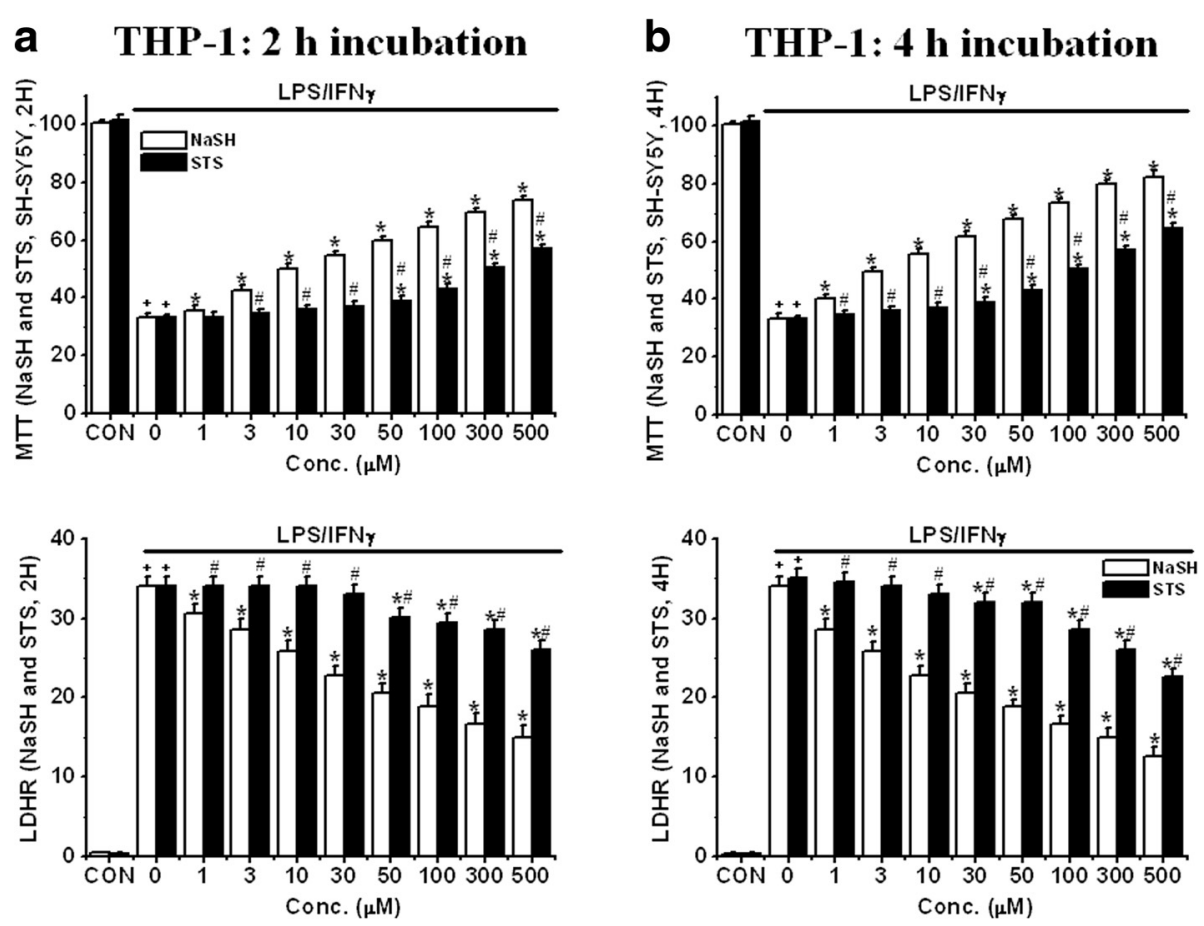

C THP-1: $8 \mathrm{~h}$ incubation
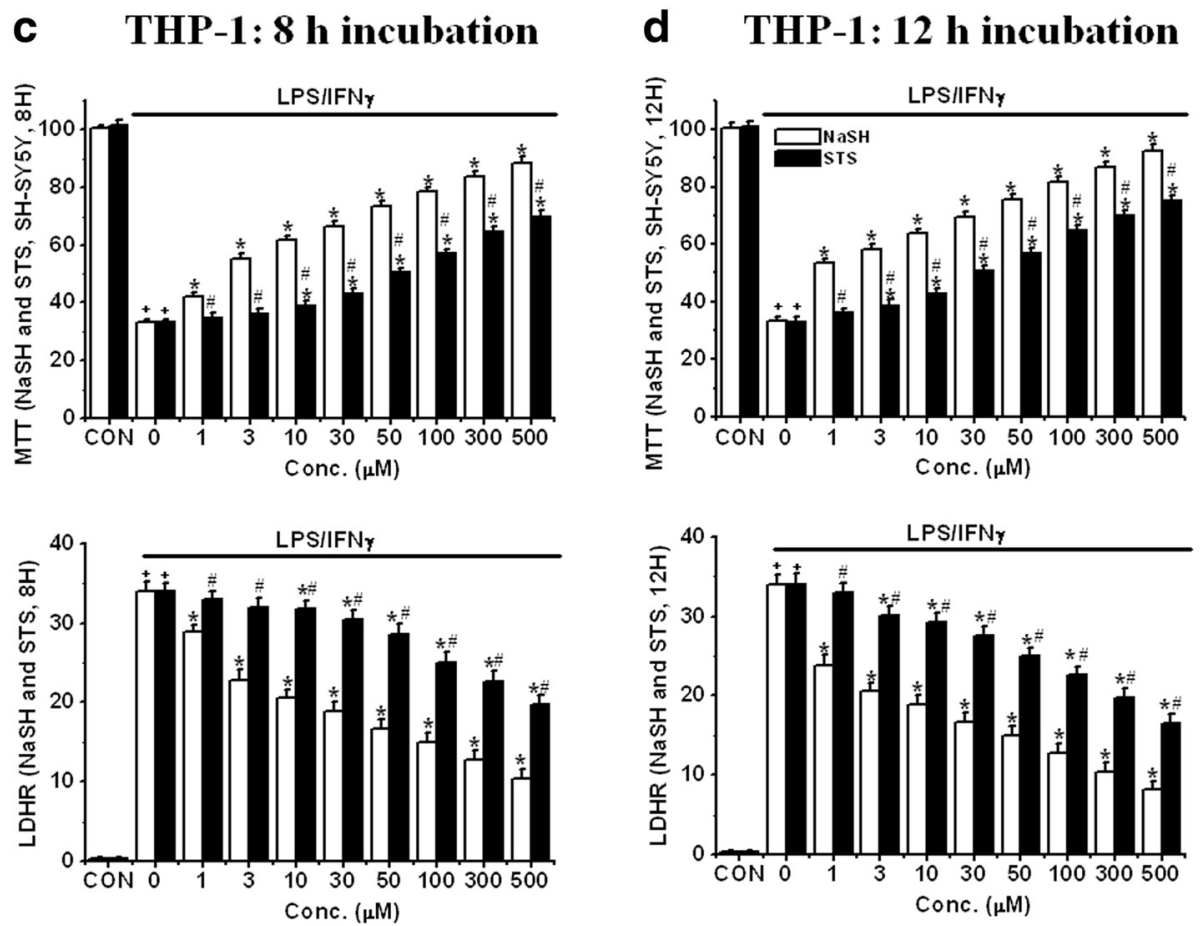

Fig. 6 Effect of treatment with NaSH or STS on SH-SY5Y cell viability changes induced by LPS/IFNY-activated THP-1 cell conditioned medium (CM) as followed by MTT and lactate LDH release assays (protocol 1). a $2 \mathrm{~h}$ pre-incubation, $\mathbf{b} 4 \mathrm{~h}$ pre-incubation, $\mathbf{c} 8 \mathrm{~h}$ pre-incubation, and $\mathbf{d} 12 \mathrm{~h}$ pre-incubation. Upper panel: MTT assay data and lower panel: LDH release assay data. Values are mean $\pm \mathrm{SEM}, n=4$. Two-way ANOVA was carried out to test significance. Multiple comparisons were followed with post hoc Bonferroni tests. ${ }^{+} P<0.01$ for LPS/IFNY-activated groups compared with CON groups in the same concentrations, ${ }^{*} P<0.01$ for $\mathrm{NaSH}$ - or STS-treated groups compared with LPS/IFNY-activated groups, ${ }^{\#} P<0.01$ for STS-treated groups compared with NaSH roups in the same concentrations (a-d). Note that both compounds attenuated a reduction of SH-SY5Y cell viability induced by LPS/IFNY-activated THP-1 cell CM in a concentration-dependent and pre-incubation time-dependent manner 

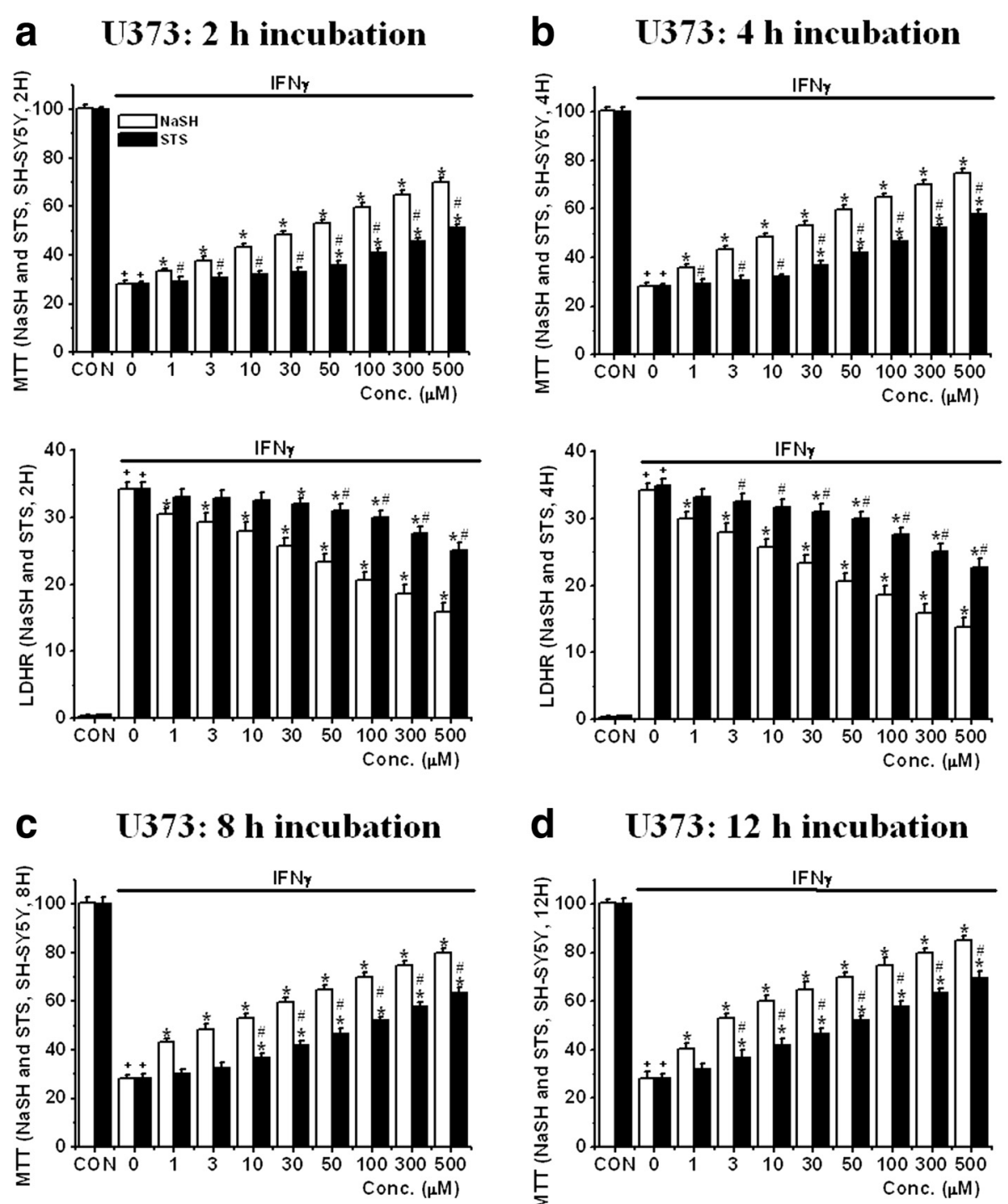

\section{d U373: 12 h incubation}
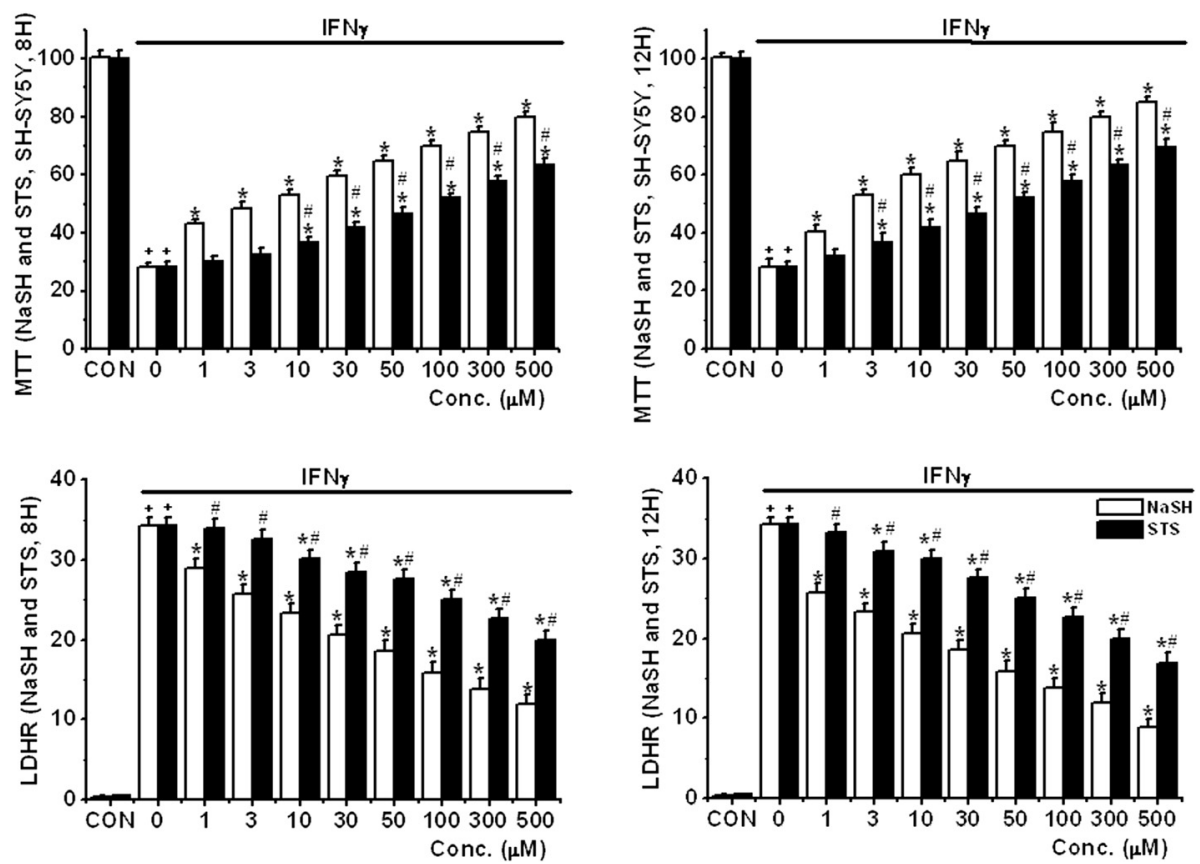

Fig. 7 Effect of treatment with NaSH or STS on SH-SY5Y cell viability changes induced by IFNY-activated U373 cell CM as followed by MTT and LDH release assays (protocol 1). a $2 \mathrm{~h}$ pre-incubation, $\mathbf{b} 4 \mathrm{~h}$ pre-incubation, $\mathbf{c} 8 \mathrm{~h}$ pre-incubation, and $\mathbf{d} 12 \mathrm{~h}$ pre-incubation. Upper panel: MTT assay data and lower panel: LDH release assay data. Values are mean $\pm \mathrm{SEM}, n=4$. Two-way ANOVA was carried out to test significance. Multiple comparisons were followed with post hoc Bonferroni tests. ${ }^{+} P<0.01$ for LPS/IFNY-activated groups compared with CON groups in the same concentrations, ${ }^{*} P<0.01$ for NaSH- or STS-treated groups compared with LPS/IFNY-activated groups, ${ }^{*} P<0.01$ for STS-treated groups compared with $\mathrm{NaSH}$ groups at the same concentrations (a-d). Note that both compounds attenuated the reduction of SH-SY5Y cell viability induced by IFNy-activated U373 CM in a concentration-dependent and pre-incubation time-dependent manner 
Table $2 \mathrm{IC}_{50}(\mu \mathrm{M})$ based on MTT (A-1 and B-1) and LDHR data (A-2 and B-2) of NaSH and STS at different pre-incubation times in THP-1 cells and U373 cells

\begin{tabular}{|c|c|c|c|c|}
\hline \multicolumn{5}{|l|}{ (A) MTT data } \\
\hline & \multicolumn{2}{|l|}{ THP-1 cells } & \multicolumn{2}{|l|}{ U373 cells } \\
\hline Pre-incubation time & $\mathrm{NaSH}$ & STS & $\mathrm{NaSH}$ & STS \\
\hline $2 \mathrm{~h}$ & $28.55 \pm 2.32$ & $121.53 \pm 3.25$ & $28.55 \pm 3.32$ & $95.53 \pm 3.25$ \\
\hline $4 \mathrm{~h}$ & $23.83 \pm 2.34$ & $96.47 \pm 2.44$ & $22.43 \pm 3.34$ & $49.63 \pm 2.44$ \\
\hline $8 \mathrm{~h}$ & $10.35 \pm 2.11$ & $53.55 \pm 2.46$ & $9.44 \pm 2.11$ & $30.27 \pm 2.46$ \\
\hline $12 \mathrm{~h}$ & $5.83 \pm 1.47$ & $35.73 \pm 1.78$ & $4.47 \pm 1.83$ & $19.57 \pm 1.78$ \\
\hline \multicolumn{5}{|l|}{ (A) LDHR data } \\
\hline & \multicolumn{2}{|l|}{ THP-1 cells } & \multicolumn{2}{|l|}{ U373 cells } \\
\hline Pre-incubation time & $\mathrm{NaSH}$ & STS & $\mathrm{NaSH}$ & STS \\
\hline $2 \mathrm{~h}$ & $15.33 \pm 0.88$ & $173.53 \pm 18.75$ & $32.48 \pm 2.32$ & $98.38 \pm 7.25$ \\
\hline $4 \mathrm{~h}$ & $3.83 \pm 0.56$ & $100.47 \pm 12.44$ & $25.18 \pm 2.21$ & $71.05 \pm 4.44$ \\
\hline $8 \mathrm{~h}$ & $2.11 \pm 0.16$ & $61.81 \pm 5.46$ & $10.17 \pm 1.11$ & $47.91 \pm 3.46$ \\
\hline $12 \mathrm{~h}$ & $1.42 \pm 0.22$ & $33.51 \pm 2.31$ & $1.84 \pm 0.28$ & $32.22 \pm 2.78$ \\
\hline
\end{tabular}

The tables summarized the $I_{50}$ results of the studies in Figs. 6 and 7. Values are mean $\pm S E M, n=4$. Two-way ANOVA was carried out to test significance. Multiple comparisons were followed with post hoc Bonferroni tests. Note that there was a significant reduction in $\mathrm{IC}_{50}$ values between any pre-incubation time groups and that there was a significant reduction in $\mathrm{IC}_{50}$ values of $\mathrm{NaSH}$ compared with those of STS in the same incubation time groups

change the viability of microglia and astrocytes under any of the experimental conditions.

\section{Activation of intracellular inflammatory pathway in microglia and astrocytes}

In the final set of experiments, we investigated the effects of pre-treatment with $\mathrm{NaSH}$ and STS at $100 \mu \mathrm{M}$ on phospho-P38 MAPK and phospho-NFkB proteins. These are indicative of intracellular inflammatory activation. The data are shown in Fig. 9. Upon exposure to the stimulants, both microglia and astrocytes showed an increase in these proteins. For microglia, P38 MAPK was increased sevenfold and NFKB eightfold. For astrocytes, P38 MAPK and NFKB were increased sevenfold. Both compounds attenuated these increases, and $\mathrm{NaSH}$ was again more powerful than STS $(\mathrm{NaSH}: 80 \%$ reduction and STS: $60-65 \%$ reduction).

\section{Discussion}

Brain damage is known to cause neuroinflammation by activating microglia and astrocytes to release proinflammatory factors such as cytokines, toxic free radicals, and proteases. Many previous publications indicate that oxidative stress in neuronal cells plays an important role in their death [25]. Indeed, we first reported that depletion of GSH in both microglia and astrocytes induces neuroinflammation and results in neurotoxicity. It is known that $\mathrm{H}_{2} \mathrm{~S}$ is a reducing agent which can increase intracellular glutathione levels. Glutathione is a major intracellular antioxidant [26] and thereby inhibits oxidative stress [11]. $\mathrm{H}_{2} \mathrm{~S}$ activates adenylate cyclase to increase $[\mathrm{cAMP}]_{\mathrm{i}}$ which has an inhibitory effect on transcription of inflammatory cytokine mRNAs [26]. All of these mechanisms may be contributing to the results reported here.

In this study, we have shown that STS has the same broad spectrum inhibition of toxic inflammatory activity as NaSH. Since neuroinflammation has been demonstrated to occur in degenerative neurological diseases such as Alzheimer's disease (AD) and Parkinson's disease (PD) $[27,28]$, STS is a potential therapeutic agent for these and other neurodegenerative disorders. It has already been approved as a treatment for arsenic poisoning and calciphylaxis in hemodialysis patients with end-stage kidney disease. This is at least partly due to an increase in $\mathrm{H}_{2} \mathrm{~S}$ and GSH in microglia and astrocytes by STS [7-10].

In these studies, we observed that the longer preincubation time with STS and $\mathrm{NaSH}$, the lower the concentrations of $\mathrm{NaSH}$ or STS to allow $50 \%$ of SH-SY5Y cell survival $\left(\mathrm{IC}_{50} \mathrm{~s}\right)$ when exposed to their CMs. This correlates with an increase in intracellular $\mathrm{GSH}$ and $\mathrm{SH}^{-}$levels in both glial cell types (Fig. 2). Those increases inhibited the proinflammatory pathways involving P38 MAP kinase and $\mathrm{NF \kappa B}$ proteins (Fig. 9). In turn, this led to production and release of the proinflammatory factors TNF $\alpha$ and IL-6 (Figs. 3 and 4). The overall result was a decrease in loss of SH-SY5Y cells in a concentration and pre-incubation time-dependent manner (Figs. 6, 7, and 8). We found that $\mathrm{NaSH}$ is more potent than STS (Tables 1, 2, and 3). This is apparently due to higher levels of intracellular GSH and $\mathrm{SH}^{-}$reached by $\mathrm{NaSH}$ compared with STS treatment.

In our previous experiments, we found that TNF $\alpha$ and IL-6, alone and in combination, did not change SHSY5Y cell viability (Fig. 5). However, they enhanced SH- 

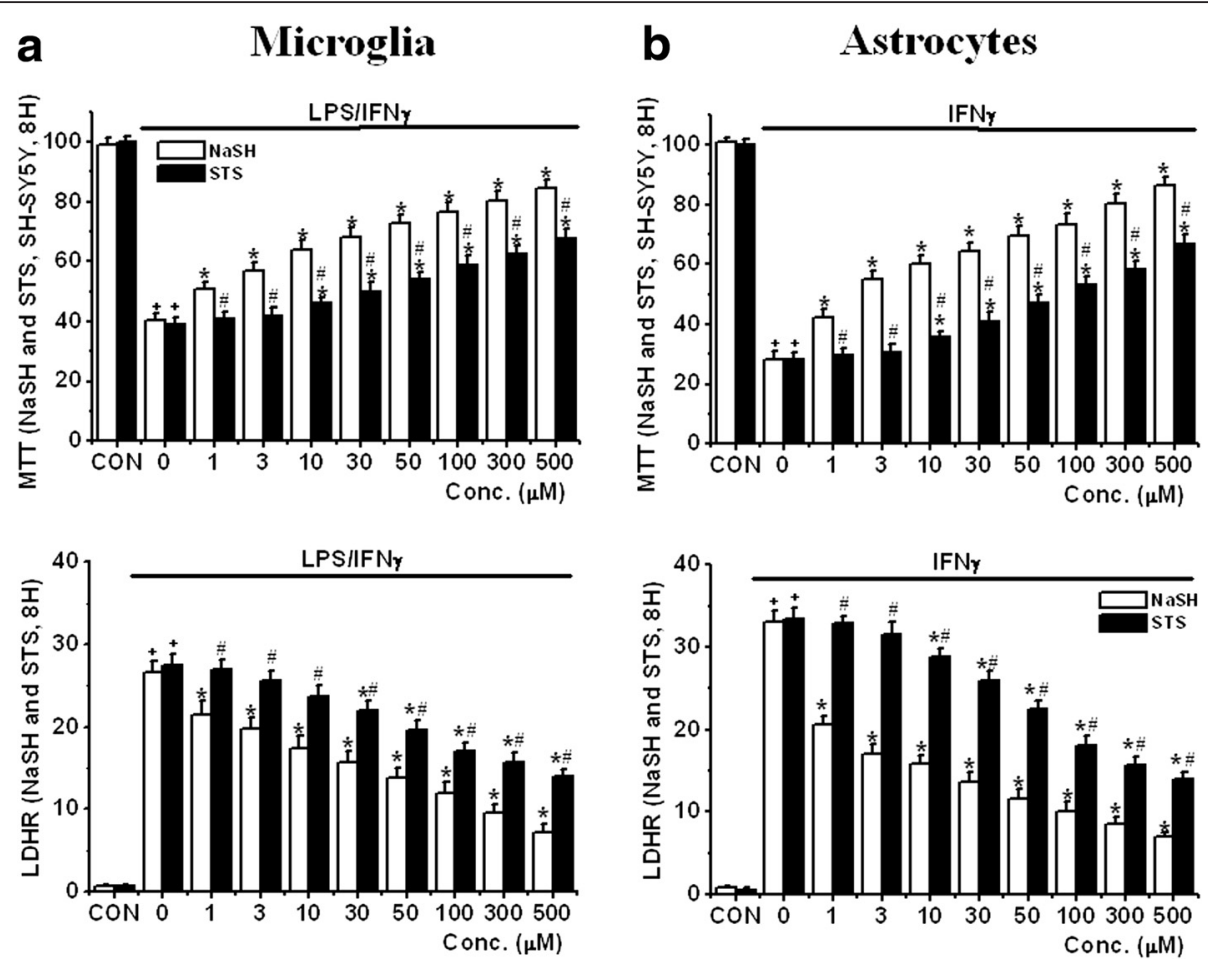

Fig. 8 Effect of pre-treatment with NaSH or STS for $8 \mathrm{~h}$ on SH-SY5Y cell viability changes induced by a LPS/IFNY-activated microglial CM and b IFNY-activated astrocytic CM as followed by MTT and LDH release assays (protocol 1). Upper panel: MTT assay data and lower panel: LDH release assay data. Values are mean $\pm \mathrm{SEM}, n=4$. Two-way ANOVA was carried out to test significance. Multiple comparisons were followed with post hoc Bonferroni tests. ${ }^{+} P<0.01$ for LPS/IFNy- (a) or IFNY-activated (b) groups compared with CON groups in each condition, ${ }^{*} P<0.01$ for NaSHor STS-treated groups compared with LPS/IFNY- or IFNY-activated groups, ${ }^{\#} P<0.01$ for STS groups compared with NaSH groups in each condition. Note that both compounds attenuated a reduction of SH-SY5Y cell viability induced by LPS/IFNY-activated THP-1 cell CM in a

concentration-dependent manner

SY5Y sensitivity to other inflammatory materials released from LPS/IFN $\gamma$-stimulated microglia and IFN $\gamma$ stimulated astrocytes $[17,20]$.

Murutani et al. [6], in HPLC-linked measurements, reported that treatment of $\mathrm{SH}-\mathrm{SY} 5 \mathrm{Y}$ cells with $\mathrm{Na}_{2} \mathrm{~S}$ increased intracellular and extracellular levels of thiosulfate, but not $\mathrm{H}_{2} \mathrm{~S}$. In the current study, we measured $\mathrm{H}_{2} \mathrm{~S}$ levels in THP-1 and U373 cells with the zinc acetate-mediated $\mathrm{H}_{2} \mathrm{~S}$-trap methods (i.e., methylene blue method). Given the known limitation of this method that utilizes highly acidic condition [29,30], we were not able to measure thiosulfate levels in the glial cells in this study.

It is known that direct inhalation of $\mathrm{H}_{2} \mathrm{~S}$ is toxic even though this gas is present in our body for a wide variety

Table $3 \mathrm{IC}_{50}(\mu \mathrm{M})$ based on MTT (A-1 and B-1) and LDHR data (A-2 and B-2) of NaSH and STS at different pre-incubation times in microglia and astrocytes

\begin{tabular}{|c|c|c|c|c|}
\hline \multicolumn{5}{|c|}{ Human microglia and astrocytes } \\
\hline \multicolumn{5}{|l|}{ (B) MTT data } \\
\hline & Miroglia & & Astrocytes & \\
\hline Pre-incubation time & $\mathrm{NaSH}$ & STS & $\mathrm{NaSH}$ & STS \\
\hline $8 \mathrm{~h}$ & $7.62 \pm 0.46$ & $68.43 \pm 3.25 *$ & $9.01 \pm 0.71$ & $77.53 \pm 3.48$ * \\
\hline \multicolumn{5}{|l|}{ (B) LDHR data } \\
\hline & Miroglia & & Astrocytes & \\
\hline Pre-incubation time & $\mathrm{NaSH}$ & STS & $\mathrm{NaSH}$ & STS \\
\hline $8 \mathrm{~h}$ & $23.12 \pm 1.46$ & $51.43 \pm 3.25 *$ & $1.32 \pm 0.11$ & $53.06 \pm 4.27 *$ \\
\hline
\end{tabular}

The tables summarized the $\mathrm{IC}_{50}$ results of the studies shown in Fig. 8. Values are mean $\pm \mathrm{SEM}, n=4$. One-way ANOVA was carried out to test significance. Note that there was a significant reduction in $\mathrm{IC}_{50}$ values of $\mathrm{NaSH}$ compared with those of STS $* 0.01$ 


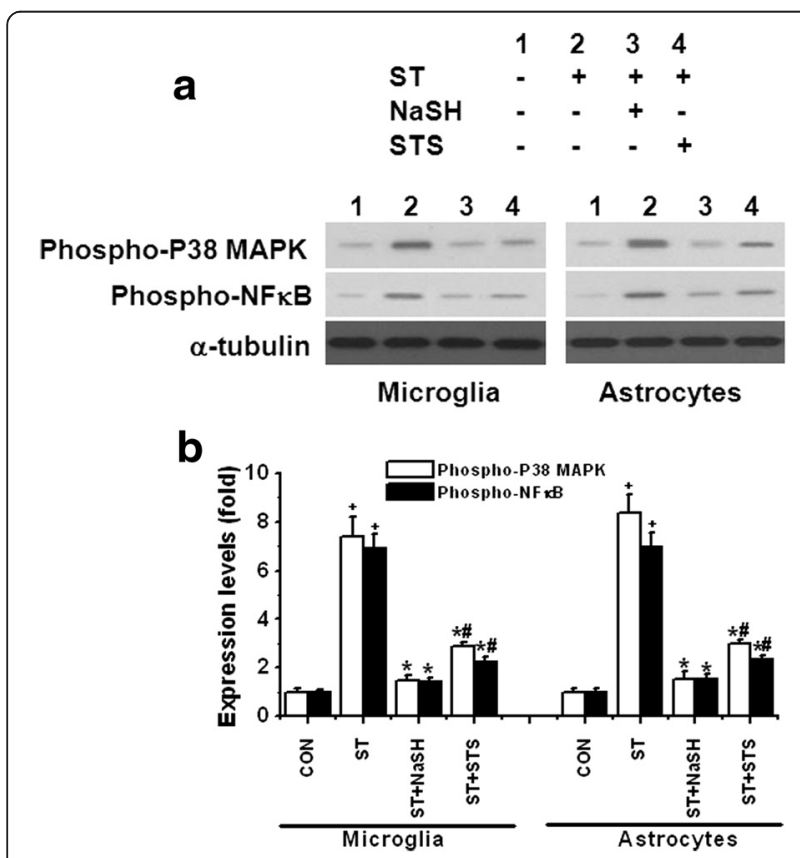

Fig. 9 Effect of pre-treatment with NaSH or STS for $8 \mathrm{~h}$ on levels of phospho-P38 MAPK and phospho-P65-NFKB in LPS/IFNy-activated human microglia a (left panel) and IFNY-activated astrocytes a (right panel). Cell extracts were prepared and the proteins separated by SDS-PAGE. Representative blots are shown in a and quantitative results in $\mathbf{b}$. To ensure equal loading, the densitometric value of each band was normalized to the corresponding band for a-tubulin. Values are mean $\pm \operatorname{SEM}, n=3$. One-way ANOVA was carried out to examine the significance of differences. ${ }^{+} P<0.01$ for LPS/IFNY- or IFNY-activated groups compared with CON groups in each condition, ${ }^{*} P<0.01$ for $\mathrm{NaSH}$ - or STS-treated groups compared with LPS/IFNY- or IFNY-activated groups, ${ }^{\#} P<0.01$ for STS-treated groups compared with $\mathrm{NaSH}$ groups in each conditions. Note that both compounds attenuated the levels of phospho-P38 MAPK and phospho-P65-NFkB in both cells

of functions. STS was not itself toxic to any cell types up to $500 \mu \mathrm{M}$ under our experimental conditions. Furthermore, STS and NaSH did not affect the viability of any glial cell type (Additional file 1: Figure S1-S3). Therefore, both agents appear to be potentially suitable as pharmaceutical drugs in conditions such as Alzheimer's disease and Parkinson's disease.

\section{Conclusions}

In this report, we have shown NaSH and STS to be potent anti-inflammatory agents and STS is $20-40 \%$ less active than $\mathrm{NaSH}$ in most assays, but there are no qualitative differences and this would merely translate into modestly higher doses to achieve the same effect. What is important is that STS is an approved agent while $\mathrm{NaSH}$ must go through many regulatory steps before it could be approved. For the present, emphasis should be on STS as a potential broad spectrum therapeutic agent.

\section{Additional file}

Additional file 1: Figure S1. Effect of $\mathrm{NaSH}$ or STS on cell viability changes after treatment for 2 days with LPS/IFNY-activated THP-1 cells (A), IFNY-activated U373 cells (B), LPS/IFNY-activated human microglia (C) and IFNY-activated human astrocytes (D) as followed by MTT assays. (A) THP-1 cells and (B) U373 cells: 12 h preincubation with NaSH or STS and (C) microglia and (D) astrocytes: $12 \mathrm{~h}$ preincubation with NaSH or STS. Values are mean $\pm S E M, n=4$. One-way ANOVA was carried out to test significance. Multiple comparisons were followed with post-hoc Bonferroni tests where necessary. Note that there was no viability change when each compound was exposed to the cells in the presence of LPS/IFNY or IFNץ. Figure S2. Effect of treatment with NaSH and STS on SH-SY5Y cell viability changes induced by LPS/IFNY-activated THP-1 cell CM (A) or IFNY-activated U373 cell CM (B) as followed by MTT assays (Protocol 2). A: THP-1 cells and B: U373 cells. After THP-1 cells and U373 cells were stimulated for 2 days with LPS/IFNy or IFNY, respectively their supernatants were transferred to SH-SY5Y cells. Then NaSH or STS was added. MTT tests were performed after 3 days. Values are mean \pm SEM, $n=4$. One-way ANOVA was carried out to test significance. Multiple comparisons were followed with post-hoc Bonferroni tests where necessary. Note that there are no viability changes when all the compounds were exposed to $\mathrm{SH}$ SY5Y cells after LPS/IFNY-activated THP-1 cell CM (A) or IFNY-activated U373 cell CM (B) were transferred. Figure S3. Effects of treatment with $\mathrm{NaSH}$ and STS on microglial and astrocytic viability changes in the presence or absence of stimulants. (A) Microglia: no stimulation, (B) Astrocytes: no stimulation, (C) Microglia: Stimulation and (D) Astrocytes: Stimulation. (A,B) After microglia and astrocytes were treated with STS and $\mathrm{NaSH}$ for 3 days MTT assays were performed. (C,D) After microglia and astrocytes were treated with STS and NaSH for $12 \mathrm{~h}$ stimulants were added. After 2 day incubation MTT assays were performed. Values are mean \pm SEM, $n=4$. Note that NaSH and STS did not change SH-SY5Y cell viability in the presence or absence of stimulants in any concentration we tested. (DOC $99 \mathrm{~kb}$ )

\section{Abbreviations}

CM: conditioned medium; GSH: glutathione; IFNY: interferon- $\gamma$; IL6: interleukin-6; LDH: lactate dehydrogenase; LPS: lipopolysaccharide; STS: sodium thiosulfate; TNFa: tumor necrosis factor-a.

\section{Competing interests}

The authors declare that they have no competing interest.

\section{Authors' contributions}

$M L, E M$ and PLM designed experiments. ML performed experiments, $M L$ and PLM analyzed data and wrote-up this manuscript. All authors read and approved the final manuscript.

\section{Acknowledgements}

The authors are grateful to Dr. Rick Saway (ricksaway1@hotmail.com) for his advice and inspiration for these experiments and to John Anderson for going over the manuscript. This research was supported by donations from the individual British Columbians.

Received: 19 October 2015 Accepted: 19 January 2016

Published online: 08 February 2016

\section{References}

1. Hayden MR, Goldsmith DJ. Sodium thiosulfate: new hope for the treatment of calciphylaxis. Semin Dial. 2010;23(3):258-62.

2. Berlin FR, Baseler LJ, Wilson CR, Kritchevsky JE, Taylor SD. Arsenic toxicosis in cattle: meta-analysis of 156 cases. J Vet Intern Met. 2013;27(4):977-81.

3. Sakaguchi M, Marutani E, Shin HS, Chen W, Hanaoka K, Xian M, et al. Sodium thiosulfate attenuates acute lung injury in mice. Anesthesiology. 2014;121(6):1248-57.

4. Tokuda K, Kida K, Marutani E, Crimi E, Bougaki M, Khatri A, et al. Inhaled hydrogen sulfide prevents endotoxin-induced systemic inflammation and improves survival by altering sulfide metabolism in mice. Antioxid Redox Signal. 2012;17(1):11-21. 
5. Shirozu K, Tokuda K, Marutani E, Lefer D, Wang R, Ichinose F. Cystathionine Y-lyase deficiency protects mice from galactosamine/lipopolysaccharideinduced acute liver failure. Antioxid Redox Signal. 2014;20(2):204-16.

6. Marutani E, Yamada M, Ida T, Tokuda K, Ikeda K, Kai S, et al. Thiosulfate mediates cytoprotective effects of hydrogen sulfide against neuronal ischemia. J Am Heart Assoc. 2015;4(11).

7. Sowers KM, Hayden MR. Calcific uremic arteriolopathy: pathophysiology, reactive oxygen species and therapeutic approaches. Oxid Med Cell Longev. 2010;3(2):109-21.

8. Sen U, Vacek TP, Hughes WM, Kumar M, Moshal KS, Tyagi N, et al. Cardioprotective role of sodium thiosulfate on chronic heart failure by modulating endogenous $\mathrm{H}_{2} \mathrm{~S}$ generation. Pharmacology. 2008;82(3):201-13.

9. Sen U, Basu P, Abe OA, Givvimani S, Tyagi N, Metreveli N, et al. Hydrogen sulfide ameliorates hyperhomocysteinemia-associated chronic renal failure. Am J Physiol Renal Physiol. 2009;297(2):F410-419.

10. Bijarnia RK, Bachtler M, Chandak PG, van Goor H, Pasch A. Sodium thiosulfate ameliorates oxidative stress and preserves renal function in hyperoxaluric rats. PLoS One. 2015;10(4):e0124881.

11. Lee M, Cho T, Jantaratnotai N, Wang YT, McGeer E, McGeer PL. Depletion of GSH in glial cells induces neurotoxicity: relevance to aging and degenerative neurological diseases. FASEB J. 2010;24(7):2533-45.

12. McGeer PL, Schwab C, Parent A, Doudet D. Presence of reactive microglia in monkey substantia nigra years after 1-methyl-4-phenyl-1,2,3,6tetrahydropyridine administration. Ann Neurol. 2003;54(5):599-604.

13. Lee M, Schwab C, Yu S, McGeer E, McGeer PL. Astrocytes produce the antiinflammatory and neuroprotective agent hydrogen sulfide. Neurobiol Aging. 2009;30(10):1523-34.

14. Lee M, Sparatore A, Del Soldato P, McGeer E, McGeer PL. Hydrogen sulfidereleasing NSAIDs attenuate neuroinflammation induced by microglial and astrocytic activation. GLIA. 2010;58(1):103-13.

15. Lee M, Tazzari V, Giustarini D, Rossi R, Sparatore A, Del Soldato P, et al. Effects of hydrogen sulfide-releasing L-DOPA derivatives on glial activation: potential for treating Parkinson disease. J Biol Chem. 2010;285(23):17318-28.

16. Singh US, Pan J, Kao YL, Joshi S, Young KL, Baker KM. Tissue transglutaminase mediates activation of RhoA and MAP kinase pathways during retinoic acid-induced neuronal differentiation of SH-SY5Y cells. J Biol Chem. 2003:278(1):391-9.

17. Lee M, McGeer E, McGeer PL. Neurotoxins released from interferon-gammastimulated human astrocytes. Neuroscience. 2013;229:164-75.

18. Encinas M, Iglesias M, Liu Y, Wang H, Muhaisen A, Ceña V, et al. Sequential treatment of SH-SY5Y cells with retinoic acid and brain-derived neurotrophic factor gives rise to fully differentiated, neurotrophic factordependent, human neuron-like cells. J Neurochem. 2000;75(3):991-1003.

19. Lee M, Kang Y, Suk K, Schwab C, Yu S, McGeer PL. Acidic fibroblast growth factor (FGF) potentiates glial-mediated neurotoxicity by activating FGFR2 IIIb protein. J Biol Chem. 2011;286(48):41230-45.

20. Lee M, Suk K, Kang Y, McGeer E, McGeer PL. Neurotoxic factors released by stimulated human monocytes and THP-1 cells. Brain Res. 2011;1400:99-111.

21. Hissin PJ, Hilf R. A flourometric method for determination of oxidized and reduced glutathione in tissues. Anal Biochem. 1976;74:214-26.

22. Klegeris A, Walker DG, McGeer PL. Toxicity of human THP-1 monocytic cells towards neuron-like cells is reduced by non-steroidal anti-inflammatory drugs (NSAIDs). Neuropharmacology. 1999;38(7):1017-25.

23. Hashioka S, Klegeris A, Monji A, Kato T, Sawada M, McGeer PL, et al. Antidepressants inhibit interferon-gamma-induced microglial production of IL-6 and nitric oxide. Exp Neurol. 2007;206(1):33-42.

24. Van Wagoner NJ, Benveniste EN. Interleukin-6 expression and regulation in astrocytes. Journal of Neuroimmunology. 1999;100:124-39.

25. Cobb CA, Cole MP. Oxidative and nitrative stress in neurodegeneration. Neurobiol Dis. 2015;doi: 10.1016/j.nbd.2015.04.020.

26. Kimura $Y$, Kimura $\mathrm{H}$. Hydrogen sulfide protects neurons from oxidative stress. FASEB J. 2004;18(10):1165-7.

27. McGeer PL, McGeer EG. Local neuroinflammation and the progression of Alzheimer's disease. J Neurovirol. 2002;8(6):529-38.

28. Whitton PS. Inflammation as a causative factor in the aetiology of Parkinson's disease. Br J Pharmacol. 2007;150(8):963-76.

29. Kabil O, Banerjee R. Redox biochemistry of hydrogen sulfide. J Biol Chem. 2010:285(29):21903-7.

30. Olson KR. Is hydrogen sulfide a circulating "gasotransmitter" in vertebrate blood? Biochim Biophys Acta. 2009;1787(7):856-63.

\section{Submit your next manuscript to BioMed Central and we will help you at every step:}

- We accept pre-submission inquiries

- Our selector tool helps you to find the most relevant journal

- We provide round the clock customer support

- Convenient online submission

- Thorough peer review

- Inclusion in PubMed and all major indexing services

- Maximum visibility for your research

Submit your manuscript at www.biomedcentral.com/submit
C Biomed Central 